\title{
Nomenclatural updates and new records in Peninsular Malaysian Pentaphylacaceae
}

\author{
T.L. Yao \\ Forest Research Institute Malaysia, Kepong 52109, \\ Selangor, Malaysia \\ yaotzeleong.frim@1govuc.gov.my
}

\begin{abstract}
Four nomenclatural updates, viz. Ternstroemia coriacea, T. palembangensis, T. penangiana and T. wallichiana, and two new records T. patens and Eurya glabra in Peninsular Malaysia are presented.
\end{abstract}

Keywords. Eurya, lectotypification, Ternstroemia

\section{Introduction}

In Peninsular Malaysia, Pentaphylacaceae Engl., nom. cons. is represented by Anneslea Wall., Adinandra Jack, Eurya Thunb., Pentaphylax Gardner \& Champ. and Ternstroemia Mutis ex L.f. These genera were previously variously included in Ternstroemiaceae (Ridley, 1922), Theaceae (Keng, 1978; Corner, 1997) and Pentaphylacaceae sensu stricto (Van Steenis, 1955; Whitmore, 1973; Yao, 2010). Phylogenetic research by Anderberg et al. (2002) suggested re-circumscription of these families. Weitzman et al. (2004) adopted an expanded Ternstroemiaceae concept, which included three tribes (genera that occur in Peninsular Malaysia are listed in parentheses): (i) Pentaphylaceae P.F.Stevens \& A.L.Weitzman (Pentaphylax), (ii) Ternstroemieae DC. (Anneslea and Ternstroemia) and (iii) Freziereae DC. (Adinandra and Eurya). This circumscription is now widely accepted and referred to as Pentaphylacaceae (Stevens, 2001 onwards; Culham, 2007; Mabberley, 2008).

A taxonomic revision of Pentaphylacaceae for the Flora of Peninsular Malaysia is in progress. In this precursory paper, confusion over the application of names for plants that occur both within and outside Peninsular Malaysia is addressed. Images of type specimens are more accessible now than ever before and their study has enabled the recognition and clarification of four misapplied names in previous Floras (Dyer, 1874; King, 1890; Ridley, 1922; Keng, 1978). These are discussed below under Nomenclatural Updates. In addition, as additional herbarium materials became available, especially from previously under-collected areas, two new records for Peninsular Malaysia, one each from Eurya and Ternstroemia, were discovered. These are discussed below under New Records. The distribution of these taxa is based on specimens and literature. The key characters of all taxa treated below are provided. A selection of Peninsular Thailand, Peninsular Malaysia and Singapore specimens deposited in BO, K, KEP, KLU, L, SING and UKMB (Thiers, continuously updated) are listed. 


\section{Nomenclatural updates}

1. Ternstroemia penangiana Choisy, Mém. Soc. Phys. Genève 14: 108 (1855); Dyer in Hook.f., Fl. Brit. India 1: 281 (1874), pro parte; King, J. Asiat. Soc. Bengal 59(2): 193 (1890), pro parte. - Fagraea dubia Wall., Numer. List 4456 (1830), nom. nud. TYPE: Malaysia, Penang, 1822, Wallich 4456 (lectotype G [G00354922], designated here; isolectotypes $\mathrm{G}$ [G00354944] pro parte, K [K000674013]).

Garcinia acuminata Wall., Numer. List 4871A (1830), nom. nud. (fide Hooker J. Linn. Soc. 14: 486).

Ternstroemia bancana Miq., Fl. Ind. Bat. Suppl.: 477 (1861); Ridley, Fl. Malay Pen. 1: 197 (1922); Keng, Tr. Fl. Malaya 3: 293 (1978). - Adinandra miquelii King, J. Asiat. Soc. Bengal 59(2): 192 (1890), nom. illeg. - TYPE: Indonesia, Bangka, Plangas, Teijsmann 3165 (lectotype U [U1742026], designated here; isolectotype BO [BO1607547]), synon. nov.

Distribution. Malaysia (Perak, Selangor, Melaka (Tanjung Tuan [Cape Rachado]), Pahang, Johor); Singapore; Sumatra (Bangka-Belitung) and Borneo.

Ecology. From lowlands to c. $600 \mathrm{~m}$ elevation, by seashore on clay, high heath forest, low undulating country over sandy soil, damp sandy plateau (Gunung Panti, Johor) and may survive burnt secondary forest. Locally common to frequent.

Selected specimens. PENINSULAR MALAYSIA: Perak: Manjung, Bruas, Jun 1900, Curtis 3442 (SING0073934); ibidem, Mar 1896, Ridley 7970 (SING0073940); Lumut, Feb 1896, Ridley s.n. (SING0074044); Simpit, 1899, Ridley 10256 (SING0074054); Pasir Panjang, 12 Apr 1937, Symington FMS43580 (KEP219633); Tanjung Hantu, 13 Mar 1940, Landon FMS34818 (KEP111785); ibidem, 18 Oct 1957, Wyatt-Smith KEP78571 (KEP111771, SING0073923); Segari Melintang F.R., 22 Jun 1964, Kochummen KEP99920 (KEP111791, SING0073933). Selangor: Hulu Selangor, Batang Kali F.R., 16 Apr 1940, Symington FMS50878 (KEP111787); Gading F.R., 20 Jul 1969, Loh FRI13391 (KEP111767). Melaka: Alor Gajah, Cape Rachado F.R., 29 Jan 1967, Ng FRI1890 (KEP111789, SING0074109), FRI1891 (KEP111780, SING0074095). Pahang: Pontian, Ulu Pontian, 7 Jun 1929, Mahamud 14967 (SING0074041); Rompin, Menchali F.R., 10 Feb 1983, Ng FRI27393 (KEP91613); ibidem, 2 Sep 1966, Rahim KEP98922 (KEP111773, SING0073927); ibidem, 3 May 1982, Vethevelu FRI29662 (KEP219634, SING0073932); ibidem, 19 Apr 1959, Wyatt-Smith KEP79180 (KEP111790, SING0073943); Ulu Sg. Anak Endau, 5 Apr 1968, Cockburn FRI8140 (KEP111757, SING0074114); Rompin River, Leban Chondong, Jul 1917, Evans 13243 (SING0073921, SING0073931). Johor: Johor Bahru, G. Pulai, Dec 1904, Ridley 12181 (SING0073929); Gn. Panti, 2 Mar 1968, Cockburn FRI7759 (KEP111772, SING0074099); ibidem, 13 Oct 1935, Corner SFN29973 (KEP111755, SING0073926); ibidem, Dec 1892, Ridley s.n. (SING0073928); Gn. Panti West, 22 Jan 1970, Everett FRI13824 (KEP111784, SING0074541); ibidem, 25 Jun 1967, Heaslett 6 (SING0073925); Kota Tinggi, 5 Sep 1965, Ng KEP118191 (KEP111786, SING0073920); Telok Balau, 4 Sep 1965, Ng KEP118175 (KEP219636); Ulu Sebol F.R., 7 Feb 1980, Mat Asri FRI25588 (KEP111788); Mersing, 
Endau, Kpg. Hubong, 22 Jul 1959, Kadim \& Mohd Noor KN424 (SING0073937); Gn. Janing, 23 Oct 1985, Wong FRI30915 (KEP219635); Lenggor F.R., 28 Aug 1997, Teo \& Tetu KL4736 (KEP111793); Pulai, 25 Apr 1922, Mohd Nur \& Kiah 7812 (SING0073930); Segamat, Kuala Palong F.R., 31 May 1970, Everett FRI14259 (KEP111758, SING0074104); Segamat W.L.R., 2 Jun 1970, Loh FRI17132 (KEP111770, SING0074100, SING0074111); Tanah Runto, 14 Feb 1890, Goodenough 1950 (SING0073924).

SINGAPORE: s.l., Cantley 464 (SING0026364); Bkt. Timah, 19 Jan 1938, Kiah SFN 34666 (SING0026354); ibidem, 1893, Ridley 5096 (SING0026360); ibidem, 1894, Ridley 6554 (SING0026363); Changi, 1889, Ridley 2028 (SING0026359); Seletar, 16 Oct 1890, Goodenough 180 (SING0026367); ibidem, Ridley 1802 (BM); ibidem, 1890, Ridley 1948 (SING0026362); Sg. Murai, 1892, Ridley 3986 (SING0026355), s.n. (SING0026356), 1893, s.n. (SING0026357).

Notes. This species was better known as Ternstroemia bancana in the Malay Peninsula but is conspecific with the earlier $T$. penangiana. This name, however, was also mistakenly widely applied for Ternstroemia coriacea (see below). Ternstroemia penangiana is easily recognised by the greyish white, angular young twigs, smooth, thick leathery lamina $(9.5-16 \times 4.3-7.5 \mathrm{~cm})$ that usually dries reddish grey-brown, ellipsoid fruits on stout pedicel (to $1.8 \mathrm{~cm}$ long, $3 \mathrm{~mm}$ thick), and a smooth to irregularly ribbed calyx cup clasping the fruit base.

There are two duplicates of Wallich 4456 deposited in Geneva. G00354922 consists of twigs, leaves, flowers, fruit fragments and has Choisy's handwriting on the sheet. This specimen is designated here as the lectotype. G00354944 is probably a mixed collection with Ternstroemia penangiana leaves and twigs and a detached fruit with an atypical warty and thickened calyx cup. Ternstroemia penangiana as treated by Dyer (1874) and King (1890) consists of two entities, namely the type, Wallich 4456, and material of Erythrochiton wallichianum Griff. (see below), which was described from Burma. Erythrochiton wallichianum Griff. is also known under the combination Ternstroemia wallichiana (Griff.) Engler. King (1890) rightly pointed out these two might not be conspecific. Dyer (1874) and King (1890) mentioned Java as part of the distribution. I couldn't find any Javanese specimens belonging to this species and the true identity of Javanese specimens determined as Ternstroemia penangiana needs further study.

Miquel (1861) gave Plangas as the type locality of Ternstroemia bancana and Teijsmann 3165 is the only collection which would have been available to Miquel from the locality mentioned. The specimen in Utrecht is hence selected as lectotype.

2. Ternstroemia coriacea Scheff., Tijdschr. Nederl. Ind. 31: 352 (1870); King, J. Asiat. Soc. Bengal 59(2): 194 (1890). - TYPE: Indonesia, Bangka, Batoe-Balai, Teysmann s.n. (holotype BO [BO-1600915]).

Ternstroemia penangiana auct. non Choisy: Ridley, Fl. Malay Pen. 1: 197 (1922), pro parte; Keng, Tr. Fl. Malaya 3: 295 (1978), pro parte. 
Distribution. Sumatra (Aceh, Riau, Bangka-Belitung); Peninsular Malaysia (Penang, Perak, Selangor, Negeri Sembilan, Melaka, Kelantan, Pahang, Johor) and Singapore.

Ecology. Primary and regenerated forest in lowlands to hills up to c. $600 \mathrm{~m}$ elevation.

Selected specimens. PENINSULAR MALAYSIA: Penang: Government Hill, Nov 1890, Curtis 1055 (SING0074034); West Hill, Oct 1886, Curtis 1055 (SING0074051); ibidem, Apr. 1890, Curtis 1055 B (SING0074045). Perak: s.l. Aug 1885, King's collector 8113 (L2405899); Batang Padang, Bkt. Tapah F.R., 3 Apr 1971, Loh FRI17373 (KEP1908, SING0074037); Tapa[h], Wray 1431 (SING0074042, SING0074048, SING0074055); Kuala Kangsar, Piah F.R., 16 Jul 1967, Kochummen FRI2470 (KEP1906, SING0074035, SING0074038). Selangor: Gombak, Bkt. Lagong F.R., 4 Feb 1962, Mohzan KEP94727 (KEP1904, SING0073922); Hulu Langat, Genting Temok, 16 Jan 1960, Gadoh KL1947 (KEP1902). Negeri Sembilan: Port Dickson, Sg. Menyala F.R., 13 Nov 1953, Sinclair SFN40153 (SING0074056, L2405897); ibidem, 9 Jul 1947, Wyatt-Smith KEP64499 (KEP1907). Melaka: s.l., Ridley s.n. (SING0074040); Sg. Udang, Oct 1893, Goodenough 1492 (SING0074050). Kelantan: Tamangan, Kpg. Gobek, Kerilla Estates, 1 Mar 1959, Mohd Shah MS485 (SING0074036), MS543 (SING0074039). Pahang: Raub, 30 Oct 1929, Strugnell 20335 (SING0074049); Rompin, Lesong F.R., 29 Jun 1972, Chan FRI16912 (KEP1598, SING0074573); ibidem, 4 May 1956, Lindong KEP83469 (KEP1909). Johor: Johor Bahru, Gn. Pulai, 12 Mar 1970, Burgess FRI9936 (KEP90086); Kluang, Kluang F.R., 21 Oct 1969, Kochummen FRI2853 (KEP1905); ibidem, 10 May 1968, Whitmore FRI8707 (KEP1599, SING74107); Mersing, Mersing-Endau road, 15 Sep 1969, Kochummen FRI2803 (SING0166137); Mersing F.R., 22 Oct 1997, Perromat KL4744 (KEP1910).

SINGAPORE: MacRitchie Reservoir, 12 Nov 1951, Sinclair SFN3942 (SING0026358); Mandai Road, 22 Apr 1941, Collector unknown SFN37271 (SING0017178, L2405898).

Notes. The true identity of many Malayan Ternstroemia coriacea specimens has been masked under the misapplied name $T$. penangiana auct. non Choisy since the 1920's. This species is characterised by dark brown terete twigs, stout petioles $(15-25 \mathrm{~mm}$ long, 3-4 mm thick), smooth, leathery oblanceolate lamina $(12.5-19 \times 4.8-8.4 \mathrm{~cm})$ that dries dark brown, ellipsoid or globose fruit on a slender pedicel (3.5-6 cm long, 2 $\mathrm{mm}$ thick), and a smooth calyx cup with flared lobes.

Only one specimen, BO-1600915 (BO), has been located with the locality information of 'Bangka, Batoe-Balai' and the vernacular name 'Prapat-darat = Me'ikoh' exactly as in the Scheffer (1870) protologue, and is, therefore, interpreted here as the holotype. Other Teysmann collections from the type locality are deposited in BO (BO-1600916), L (L2405910, L2405911) and U (U1742028).

3. Ternstroemia palembangensis Kobuski, J. Arnold Arbor. 44: 427 (1963). TYPE: Indonesia, Sumatra, Palembang, Ond. Afd. Banjoeasin en Koeboestreken bij Bajoenglintjir, L.J.W. Dorst 69T-1P-125 (holotype BO [BO-135020]; isotypes A [A00025066] (fragm.), BO [BO-135018, BO-135019], L [L0012421]). 
Ternstroemia corneri H.Keng, Gard. Bull. Sing. 29: 143 (1977); Keng, Tr. Fl. Malaya 3: 293 (1978); Kochumen, Tr. Fl. Pasoh For.: 426 (1997). - TYPE: Malaysia, Johor, Sungai Berassau, Mawai-Jemaluang Road, low altitude, in swampy forest, 6 Feb 1935, E.J.H. Corner SFN28740 (holotype SING [SING0055550], isotypes A, B, BM, K [K000674016], KEP [KEP116328], L [2400447]), synon. nov.

Distribution. Peninsular Malaysia (Perak, Selangor, Negeri Sembilan, Johor); Singapore and Sumatra (South Sumatra).

Ecology. Lowland fresh water swamp forests or edge of streams, locally common; rarely in the valleys of hill forests.

Selected specimens. PENINSULAR MALAYSIA: Perak: Hilir Perak, Changkat Jong, 17 Feb 1976, Sidek SK466 (KEP219637, SING0073945); Sg. Hidup, 17 Feb 1975, Mohd Shah \& Shukor MS3462 (KEP116320, SING0073944). Selangor: Gombak, Bkt. Lagong F.R., 16 May 1947, Ali et al. 52239 (KEP1903). Negeri Sembilan: Jelebu, Pasoh F.R., 11 Aug 1988, LaFrankie 3217 (KEP103117). Johor: Kota Tinggi, Mawai, 13 Apr 1936, Corner SFN30888 (SING0073949, L2400484); ibidem, 13 Jan 1938, Ngadiman SFN34736 (BO, SING0073946, L2400445, L2400446); Mawai-Jemaluang Rd., Sg. Kayu, 6 Feb 1937, Corner SFN32245 (KEP116327, SING0073947, L2400483); Sg. Gambut, 23 Jul 1939, Corner SFN36815 (KEP111742, SING0073950, L2400485); Sg. Sedili, Danau, 27 Mar 1932, Corner s.n. (SING0073948); Sg. Kayu, 23 Oct 1936, Kiah SFN32158 (SING0073951, L2400482); 25 Jul 2006, Mersing, Lenggor F.R., Teo \& Din KL5278 (KEP126426).

SINGAPORE: Mandai Forest, 6 Jan 2009, Gwee et al. SING2009-30 (SING0116942); Nee Soon Freshwater Swamp Forest, 18 Apr 2005, Samsuri et al. SING2005-121 (SING0061029); Upper Seletar Forest, 25 Aug 2011, Gwee SING2011-331 (SING0166745).

Notes. Malayan specimens of this taxon were placed in Ternstroemia corneri which was regarded as a species endemic to the Malay Peninsula. However, in the diagnostic characters of vegetative bracts on young twigs and scale-like scars on older twigs, the large oblanceolate leaves (19-)23.5-36.5 cm long, and at least 12 pairs of clearly visible lateral veins on lower leaf surface, all specimens determined as Ternstroemia corneri match with the type material of T. palembangensis and other Sumatran material.

4. Ternstroemia wallichiana (Griff.) Engl. in Engler \& Prantl, Nat. Pflanzenfam. Nachtr. 1: 246 (1897); Keng, Tr. Fl. Malaya 3: 295 (1978). - Erythrochiton wallichianum Griff., Proc. Linn. Soc. 1: 282 (1846), Notul. Pl. Asiat. 4: 565 (1854). TYPE. Myanmar, Mergui, Madamacan Island, Dec 1834, W. Griffith 866 [number tag is upside down on the holotype sheet, seemingly '998'] (lectotype K [K000674012], designated here; isolectotype K [K000674011]).

Ternstroemia penangiana auct. non Choisy: Dyer in Hook.f., Fl. Brit. India 1: 281 (1874), pro parte; Ridley, Fl. Malay Pen. 1: 197 (1922), pro parte. - Ternstroemia wallichiana Ridl., Fl. Malay Pen. 1: 198 (1922). 
Distribution. India (Andaman and Nicobar Islands (Prasad et al., 2009)); Myanmar (Myeik (Mergui)); Central Thailand (Nakhon Nayok), Peninsular Thailand (Phangnga, Nakhon Si Thammarat, Satun (Ko Tarutau), Songkhla); Peninsular Malaysia (Perlis, Kedah (incl. P. Langkawi), Penang, Perak, Kelantan, Terengganu (incl. P. Redang), Pahang (incl. P. Tioman), Johor (incl. P. Tinggi)); Singapore and East Nusa Tenggara (Flores, Kostermans 22126, 22127 (BO)).

Ecology. Exposed areas such as the seashore, riversides and secondary forests.

Selected specimens. CENTRAL THAILAND: Nakhon Nayok: Muang, Khao Yai National Park, Mo Singto, 29 Mar 2002, Tanthana \& Boonkongchart 39 (L2400316). PENINSULAR THAILAND: [Lower Siam] 17 Mar 1919, Hamid 3866 (SING74059). Nakhon Si Thammarat: s.1., 15 Sep 1960, Sangkachand 694 (L2400319). Phangnga: Ton Bariwat W.S., 11 Dec 2004, Gardner et al. ST1243 (KEP204682). Satun: Tarutao N.P., 31 Mar 2006, Gardner ST2530 (KEP225500). Songkhla: Khao Nam Khang N.P., 27 Jan 2006, Gardner ST2256 (KEP172002). PENINSUlAR MALAYSIA: Perlis: Titi Tinggi, Rimba Mas Mas F.R., 5 Jun 1941, Symington 57049 (KEP191849). Kedah: Kota Setar, Tampoi F.R., 14 Jul 1947, WyattSmith 64266 (KEP191847); Kubang Pasu, Sg. Badak F.R., 27 Apr 2006, Teo \& Din KL5235 (KEP125591); Langkawi, G. Raya FR, G. Raya, Lubuk Sembilang, 16 Mar 1990, Kamarudin FRI31365 (SING0074118); P. Dayang Bunting, 12 May 1983, Collector unknown FRI22907 (KEP91617); ibidem, 15 Sep 1983, Collector unknown FRI22918 (KEP91618); Near Telaga Tujuh, 24 Feb 1983, Kochummen FRI26087 (KEP91616, SING0074086); Telok Datai, 21 Nov 1921, Mohd Haniff \& Mohd Nur 7514 (SING0074058); Sik, Ulu Muda F.R., 16 Jan 1969, Bray FRI11523 (KEP1901, SING0074115). Penang: Penang Hill, Ridley 9351 (SING0074067); ibidem, 15 May 1934, Henderson SFN21301 (KEP191846, SING0074062); ibidem, 20 Apr 1938, Kiah SFN35324 (KEP1600, SING0074057); Government Hill F.R., 8 May 1926, Hashim FMS11665 (KEP191852); Goverment Hill, Jun 1890, Curtis 905 (SING0074089); ibidem, Apr 1897, Curtis 3283 (SING0074061); ibidem, 11 May 1926, Mohd Hashi 11670 (SING0074047); Waterfall Gardens, 27 Mar 1915, Burkill 802 (SING0074088), ibidem, Apr 1940, Nauen s.n. (SING0074074); West Hill road, Jun 1886, Curtis 905 (SING74043), Apr 1890, Curtis 905 (SING0074046), 905 B (SING0074052). Perak: Hulu Perak, Temengor F.R., Sg. Bekek Trail, 20 Feb 1994, Chua et al. FRI40530 (KEP191843). Kelantan: Kuala Krai, Stong F.R., 24 Mar 2007, Lim et al. FRI52931 (KEP142688, SING0109964, L4212024); Machang, Bkt. Baka F.R., 23 Oct 2008, Teo \& Din KL5606 (KEP163734). Terengganu: s.1., 22 Aug 1889, Ridley s.n. (SING0074066); Dungun, Rantau Abang Nursery, 28 May 1986, [Teo \& Perromal] T\&P 1023 (SING0074068); Kuala Terengganu, P. Pinang, 3 Aug 1998, Khairuddin FRI35403 (KEP224227, SING0166136); P. Redang, Pasir Mak Simpan, 11 May 1977, Liew 232 (SING0074614); Kingal [Kijal?], 8 Mar 1973, Ahmad AS112 (SING0074064). Pahang: Jerantut, Kuala Tahan, 10 May 1890, Ridley 1425 (SING0074065); Kuantan, Balok F.R., Kpg. Balok, 28 Mar 1919, Yeop FMS3146 (KEP191851, SING0074090); Bkt. Galing, 24 Oct 1923, Mahmud FMS6685 (KEP191853); Teluk Sisek, 29 Mar 1920, Yeop FMS878 (KEP191850, SING0074073); Rompin, Tasik Ayer Puteh, 7 Nov 1929, Mahamud FMS17177 (KEP191845, SING0074087); P. Tioman, Ayer Batang, 24 May 1927, Henderson 18464 (KEP191842, SING0074063). Johor: Batu Pahat, Banang F.R., 18 Aug 1953, Lindong \& Santiago 71527 (KEP191848); P. Tinggi, 16 May 1954, Sinclair SFN40285 (SING0074070).

SINGAPORE: Batu Putey, 18 Jun 1890, Goodenough 1648 (SING0026369); Changi, 1899, 
Ridley 4646 (SING0026370); Chua Chu Kang, 1894, Ridley 6093 (SING0026361); P. Tekong, Dec 1890, Ridley PT1807 (BO-1604086, SING0026368), PT1951 (SING0026371).

Notes. This species is distinctive in its narrowly elliptic-oblanceolate leaves, which become reddish brown while drying and are covered with minute raised dashes on both surfaces, and the almost globose fruits with a thick and warty calyx cup.

\section{New records}

1. Ternstroemia patens (Korth.) Choisy, Mém. Soc. Phys. Genève 14: 107 (1855); Kobuski, J. Arnold Arbor. 44: 423 (1963). - Reinwardtia patens Korth., Verh. Nat. Gesch. Ned. Bezitt., Bot.: 102, t. 12 (1840/41). - TYPE: Indonesia, Sumatra, Doekoe, P.W. Korthals s.n. (lectotype L [L0012422], designated by Kobuski (1963: 424); prob. isolectotypes L [L0012423], K [K000768053]).

Distribution. Peninsular Malaysia (Terengganu, Pahang, Johor); Sumatra (West Sumatra, Bengkulu); Java (Banten, West Java, Central Java); Borneo and Maluku.

Ecology. Lowland primary forest.

Specimens examined. PENINSULAR MALAYSIA: Terengganu: Setiu, Bkt. Kesing, 25 Sep 1991, Teo \& Remy KL4080 (KEP116346); ibidem, 29 Jul 1993, Perromat \& Teo KL4270 (KEP116344). Pahang: Rompin, Lesong F.R., 12 Jun 1979, Chan FRI23917 (KEP116345, SING0074119). Johor: Kota Tinggi, Mawai-Jemaluang Road, Sg. Kayu, 14 Apr 1935, Corner SFN29244 (SING0073953); ibidem, 17 Mar 1937, Kiah SFN32416 (SING0073956).

Notes. Keng (1978) enumerated seven Ternstroemia species for Peninsular Malaysia and Latiff et al. (1998) added one more. The new record of Ternstroemia patens reported here is characterised by obovate-elliptic, medium-sized leaves $(10-12.5 \times$ 4-5.5 cm), that dry olive green with a dull yellowish green midrib contrasting with the lighter lamina, and a single-seeded ovoid fruit with a relatively small calyx cup (7 $\mathrm{mm}$ across).

2. Eurya glabra (Blume) Korth., Verh. Nat. Gesch. Ned. Bezitt., Bot. 2: 114 (1841); Miquel, Fl. Ned. Ind. 1(2): 472 (1859); Kobuski, Ann. Missouri Bot. Gard. 25: 342 (1938); De Wit, Bull. Jard. Bot. Buitenz. III, 13: 350 (1947). - Geeria glabra Blume, Bijdr. Fl. Ned. Ind. 3: 125 (1825). - TYPE: Indonesia, Java, Mt. Gede Pangrango, near crater, Blume s.n. (lectotype BO, designated by De Wit (1947: 351); probable isolectotypes L [L0624616, L0624621], GH [HUH00024968], M [M0112026, M0112027, M0112029], NY [NY003538287, NY00353828]).

Eurya nitida var. siamensis auct. non (Craib) H. Keng: Keng, Tree Fl. Mal. 3: 282 
(1978).

Distribution. Peninsular Malaysia (Perak, Pahang, Terengganu); Sumatra (Lampung) and Java (West Java).

Ecology. In Peninsular Malaysia, it is known only from montane ericaceous forests on high mountains at 1000-2100 m a.s.l.

Specimens examined. PENINSULAR MALAYSIA: Perak: Kuala Kangsar, Korbu F.R., Gn. Korbu, 21 Jul 1933, Symington FMS31464 (KEP1597). Pahang: Cameron Highlands, Dec 1951, Johnston AMJ70 (SING0082584); Gn. Brinchang, 18 Aug 2006, Kiew RK5363 A (KEP116802, SING0092767); ibidem, Whitmore FRI15417 (KEP192299); ibidem, 12 Aug 1986, Wong FRI35238 (KEP1596, SING0081972, SING0082588). Terengganu: Gn. Padang, Jun 1937, Moysey \& Kiah SFN31046 (SING0082585).

Notes. Keng (1978) listed three species of Eurya for Peninsular Malaysia, E. acuminata, E. nitida and E. trichocarpa. Eurya glabra resembles Eurya nitida in its glabrous young twigs, terminal leaf buds and the outer surface of the calyx. However, Eurya glabra is characterised by its conspicuous 9-13 pairs of lateral veins (vs. less distinct 6-9 lateral veins in E. nitida), by a calyx that is densely pubescent on the inner surface and a ciliate margin (glabrous in E. nitida), by the 17-21 stamens (up to 12 in $E$. nitida), and in having filaments longer than the anthers (anthers longer than filaments in E. nitida). Neither female flowers nor fruit are known from Peninsular Malaysia. Two varieties are recognised in Eurya glabra (De Wit, 1947) but only the type variety occurs in Peninsular Malaysia.

ACKNOWLEDGEMENTS. The present study is part of the 'Flora of Peninsular Malaysia Project' funded by the Ministry of Science, Technology and Innovation (Project No. 01-0401-0000 Khas2), and the Ministry of Natural Resources and Environment under the 10th and 11th Malaysian Plans. Curators, keepers and managers of herbaria (BM, BO, G, K, KEP, KLU, L, SING and UKMB) are thanked for allowing me to examine the specimens in their holdings, reproducing and sending images of types, making their specimen images available online, and sharing their specimen data. I thank Suzana Sabran (SAN), who is revising Bornean Ternstroemia, for drawing my attention to the occurrence of T. patens in Peninsular Malaysia. Ruth Kiew (KEP), David Middleton (SING) and two anonymous reviewers are gratefully acknowledged for their critical and constructive comments to improve the manuscript.

\section{References}

Anderberg, A.A., Rydin, C. \& Källersjö, M. (2002). Phylogenetic relationships in the order Ericales s.l.: analyses of molecular data from five genes from the plastid and mitochondrial genomes. Amer. J. Bot. 89: 677-687.

Corner, E.J.H. (1997). Theaceae. In: Wayside tree of Malaya, 4th ed., 2: 719-729. Kuala Lumpur: The Malayan Nature Society. 
Culham, A. (2007). Pentaphylacaceae. In: Heywood, V.H., Brummitt, R.K., Culham, A. \& Seberg, O. (eds) Flowering Plant Families of the World: 248-249. London: Royal Botanic Gardens, Kew.

De Wit, H.C.D. (1947). A revision of the genus Eurya Thunb. (Theac.) in the Malay Archipelago (including New Guinea and South of The Philippines). Bull. Jard. Bot. Buitenzorg, series III, 17: 329-375.

Dyer, W.T.T. (1874). Ternstroemiaceae. In: Hooker, J.D. (ed) The Flora of British India 1: 279-294. London: L. Reeve \& Co.

Keng, H. (1978). Theaceae. In: Ng, F.S.P. (ed) Tree Flora of Malaya 3: 275-296. Kuala Lumpur: Longman.

King, G. (1890). Ternstroemiaceae. J. Asiat. Soc. Bengal 59(2): 185-206.

Kobuski, C.E. (1963). Studies in the Theaceae XXXIV: Some Asiatic taxa of Ternstroemia. J. Arnold Arbor. 44: 421-433.

Latiff, A., Natrah, M. \& Zainudin Ibrahim, A. (1998 ['1996']). Ternstroemia magnifica Stapf ex Ridley (Theaceae) and Kibatalia macrophylla (Pierre) Woodson (Apocynaceae), two species new to Peninsular Malaysia. Gard. Bull. Singapore 48: 195-200.

Mabberley, D.J. (2008). Mabberley's Plant-Book, 3rd edition. Cambridge: Cambridge University Press.

Miquel, F.A.G. (1861). Ternstroemiaceae. In: Miquel, F.A.G. (ed) Flora Indiae Batavae, supplementum primum. Prodromus Florae Sumatranae 3: 476-482. Amsterdam: C.G. van der Post.; Utrecht: C. van der Post. Jr.; Leipzig: bij. Fried. Fleischer.

Prasad, P.R.C., Reddy, C.S., Iakhsmi, R.K.V., Kumari, P.V., Raza, S.H. (2009). Angiosperm of North Andaman, Andaman and Nicobar Islands, India. Check List 5: 254-269.

Ridley, H.N. (1922). Ternstroemiaceae. In: Ridley, H.N. (ed) The Flora of the Malay Peninsula 1: 192-209. London: L. Reeve \& Co.

Scheffer, R.H.C.C. (1870). Observationes phytographicae, pars II. Natuurk. Tijdschr. Ned.Indië 31: 338-375.

Stevens, P.F. (2001 onwards). Angiosperm Phylogeny Website. Version 13 (last updated on 7 July 2016). http://www.mobot.org/MOBOT/research/APweb/ (accessed on 20 Aug. 2016).

Thiers, B. (continuously updated). Index Herbariorum: A global directory of public herbaria and associated staff. New York Botanical Garden's Virtual Herbarium. http://sweetgum. nybg.org/science/ih/ (accessed on 27 Aug. 2016).

Van Steenis, G.G.G.J. (1955). Pentaphylacaceae. In: Van Steenis, G.G.G.J. (ed) Flora Malesiana, Series I, 5: 121-124. Jakarta: Noordhoff-Kolff N.V.

Weitzman, A.L., Dressler, S. \& Stevens, P.F. (2004). Ternstroemiaceae. In: Kubitzki, K. (ed) The Families and Genera of Vascular Plants 6: 450-462. Heidelberg: Springer.

Whitmore, T.C. (1973). Pentaphylacaceae. In: Whitmore, T.C. (ed) Tree Flora of Malaya 2: 308. Kuala Lumpur: Longman.

Yao, T.L. (2010). Pentaphylacaceae. In: Kiew, R., Chung, R.C.K., Saw, L.G., Soepadmo, E. \& Boyce, P.C. (eds) Flora of Peninsular Malaysia, Series II, 1: 161-164. Kuala Lumpur: Forest Research Institute Malaysia. 
